\title{
A LÓGICA PERVERSA dA COLABORAÇÃO PREMIADA NO PROCESSO PENAL BRASILEIRO: POR QUE (AINDA) É NECESSÁRIO FALAR SOBRE O GARANTISMO DE FERRAJOLI?
}

\author{
Juliano Keller do Valle ${ }^{1}$ \\ Marcos Leite Garcia ${ }^{2}$
}

\begin{abstract}
RESUMO: A presente pesquisa pretende investigar o instituto da delação premiada no Brasil, analisando primeiramente o seu conteúdo existente na legislação existente no país, bem como no Código Penal e Processual Brasileiro. Com efeito, busca-se a partir da leitura acerca da Teoria do Garantismo Penal, estabelecer parâmetros e critérios racionais que efetivem a estrita legalidade defendida por Ferrajoli no âmbito da delação premiada. De igual forma o texto tem a pretensão de estabelecer a discussão acerca do grau de legitimidade do Estado ao utilizar da barganha processual penal introduzida através da Lei 12.850/2013 como forma de aplicação ou não de punição.
\end{abstract}

Palavras-chave: Constituição. Direito Penal. Processo Penal. Delação Premiada. Garantismo.

\section{THE PERVERSE LOGIC OF THE COLLABORATION AWARDED IN THE BRAZILIAN CRIMINAL PROCESS: WHY IS IT (STILL) NECESSARY TO TALK ABOUT THE GARANTISMO OF FERRAJOLI?}

\begin{abstract}
This research intends to investigate the institute of awarded delation in Brazil, analyzing firstly its contents in of the legislation in the country, as in the Brazilian Penal and Penal Processual Code. It is wanted from the reading of the "Teoria do Garantismo Penal" establish parameters and rational criteria that execute the strict legality defended by Luigi Ferrajoli about awarded delation. Likewise, the text intends to establish the discussion about the degree of legitimacy of the State by using the criminal procedural bargain introduced through Law 12.850 / 2013 as a form of application or not of punishment.
\end{abstract}

Keywords: Constitution. Criminal Law. Criminal proceedings. AwardWinning. Garantismo.

\footnotetext{
* Mestre em Ciência Jurídica pela Universidade do Vale do Itajaí (UNIVALI/CPGD). Professor de Processo Penal da Graduação da Universidade do Vale do Itajaí (UNIVALI). Professor do Curso de Especialização em Ciências Criminais do Complexo de Ensino Superior de Santa Catarina (CESUSC). Membro Efetivo do Instituto dos Advogados de Santa Catarina (IASC). Advogado Criminalista. Curriculum Lattes: http://lattes.cnpq.br/3715543483481844.

** Doutor em Direitos Fundamentais (2000); Master em Direitos Humanos (1990); Ambos cursos realizados no Instituto de Direitos Humanos da Universidade Complutense de Madrid, Espanha. Realizou estagio pós-doutoral na Universidade de Santa Catarina entre 2012 e 2103. Desde 2001 professor do Programa de Pós-Graduação Stricto Sensu em Ciência Jurídica, Cursos de Mestrado e Doutorado, e do Curso de Graduação em Direito da Universidade do Vale do Itajaí (UNIVALI)- Santa Catarina. Da mesma maneira, desde 2015 professor do Programa de Pós-Graduação em Direito, Curso de Mestrado, da Universidade de Passo Fundo (UPF) - Rio Grande do Sul. E-mail: mleitegarcia@terra.com.br
} 


\section{INTRODUÇÃO}

O presente trabalho terá como objetivo estabelecer reflexões acerca do atual panorama jurídico criminal no contexto das últimas modificações introduzidas pela Lei 12.850/2013, que estabeleceu novos parâmetros para a persecução penal.

Com efeito, o marco teórico proposto no final do século XX pelo Mestre Luigi Ferrajoli estabeleceu critérios e ponderações (pesos e contrapesos) de ordem constitucional ao exercício do poder de punir do Estado com o objetivo de dimensionar o grau de legitimidade ou ilegitimidadedos elementos de Controle Social, da seletividade do Direito Penal, da flexibilidade dos Direitos Fundamentais e de suas Garantias, entre outras questões de igual relevância.

O texto trará para a discussão o ponto de inflexão às garantias processuais penais secularmente consagradas -através da atual lógica neoliberal imposta pela visão da escola da Análise Econômica do Direito (AED) via uso indevido da Lei 12.850/2013, que não só seleciona quem e como se deve punir, mas também se utiliza do maniqueísmo do discurso do bem contra o mal, como fórmula para incutir nos sujeitos processuais (juízes e promotores) a aplicação plena do 'pleabargain' aos escolhidos - 'labeling approach'.

O método utilizado para a Fase de Investigação e o Relato de Pesquisa será o Indutivo3, cuja premissa menor é a força transformadora da Sustentabilidade e como é possível averiguar a viabilidade de suas promessas civilizacionais ou de relações entre humanos e não humanos por meio das ideologias ou utopias que a fundam - premissa maior. Para se desenvolver a Fase de Tratamento dos Dados, selecionou-se o Método Cartesiano ${ }^{4}$. As técnicas selecionadas ao cumprimento dos métodos eleitos são a Pesquisa Bibliográfica e Documental5, a Categoria6 e o Conceito Operacional7, quando necessários.

\footnotetext{
3 “[...] base lógica da dinâmica da Pesquisa Científica que consiste em pesquisar e identificar as partes de um fenômeno e colecioná-las de modo a ter uma percepção ou conclusão geral”. PASOLD, 2015, p. 213.

4 “[...] base lógico-comportamental proposta por Descartes, [...], e que pode ser sintetizada em quatro regras: 1. duvidar; 2. decompor; 3. ordenar; 4. classificar e revisar". PASOLD, 2015, p. 212.

5 “[...] Técnica de investigação em livros, repertórios jurisprudenciais e coletâneas legais". PASOLD, 2015, p. 215.

6 “[...] palavra ou expressão estratégica à elaboração e/ou à expressão de uma idéia”. PASOLD, 2015,. p. 205.

7 “[...] definição estabelecida ou proposta para uma palavra ou expressão, com o propósito de que tal definição seja aceita para os efeitos da ideia exposta”. PASOLD, 2015, p. 205.
} 
1. DA INTERVENÇÃO MÍNIMA DO DIREITO PENAL PARA A INTERVENÇÃo MÁXIMA NA FORMA DE UMA DEFESA SOCIAL

Com o fim dos regimes antidemocráticos que prevaleciam em países como o Brasil, foi a partir dos anos 1980 que entrou em processo de crise o discurso intervencionista penal estatal, até então vigente. Referida ideologia, afirmava que o crime não tinha realidade ontológica e que os conflitos sociais ou problemas que realmente existiam só poderiam ser equacionados através da negociação de todas as partes envolvidas (ZAFFARONI, 2006, p.7).

A partir de então, grupos que viviam à margem da discussão acerca da política criminal à época vigente, entre eles os depois identificados como alternativos (ZAFFARONI, 2006, p.7 $)^{8}$, que, permeados por ideologias de cunho de "esquerda" ${ }^{9}$, redimensionaram a postura do Direito Penal, através de teorias, entre elas, abolicionistas, que, em sentido amplo, recusavamse a admitir a legitimidade do Direito Penal, voltando-se contra a intervenção punitiva do Estado, tendo em vista a ausência de fundamentos para a aplicação da pena, em razão da violência que a mesma produzia, segundo aqueles.

Desta feita, as teses abolicionistas fincavam, também, como objetivo essencial a ser alcançado, a paz social, entretanto, a aflição e o tratamento despendido ao apenado era desumano e degradante, eis que contrário à própria razão democrática já vigente.

A crítica também se valia de que o sistema penal era subserviente apenas a um setor hegemônico, portanto, apenas simbólico na medida em que apenas trazia uma falsa impressão de justiça justificante aos demais.

${ }^{8}$ O episódio responsável que deu origem ao movimento no Brasil, ocorreu em 25 de outubro de 1990, quando o periódico paulista Jornal da Tarde, veiculou matéria com o título de "Juízes Gaúchos colocam Direito Acima da Lei”, colocando o grupo na vanguarda, inclusive no encontro promovido em Florianópolis/SC naquele mesmo período, pioneiro na profusão daquela nova ideologia do Direito. ANDRADE, Lédio Rosa de. O que é Direito Alternativo?.<Disponível em http://www.amc.org.br. Acesso em 20 de jun. de 2007.

${ }^{9} \mathrm{O}$ sentido do termo de "esquerda" de cunho eminentemente ideológico aqui suscitado, pode ser percebido na apresentação feita por Ludwig acerca do Direito Alternativo e a opção feita por um novo sujeito histórico: " [...] é possível configurar a essência da alternatividade - no sentido da determinação mais geral - e que se expressa nas formas específicas do 'uso alternativo', do 'positivismo de combate' e do 'direito alternativo em sentido estrito'. Nesse sentido, a alternatividade como categoria aparece em seu maior grau de abstração, na condição de alternatividade em geral. Ou seja, há uma alternatividade comum às diferentes formas de manifestação. Na especificidade de cada uma das formas de manifestação, a alternatividade, segundo o autor, caracteriza-se pelo uso alternativo do direito, como sendo a atuação que visa a utilização das contradições, lacunas e ambigüidades dos sistema. [...] A segunda manifestação específica denominada de positivismo de combate visa à eficácia dos direitos positivados, porém sonegados, porque não aplicados, quando do interesse das classes populares; enfim, o nível do direito alternativo em sentido estrito, resultante do 'pluralismo jurídico'. O alternativo, aqui, caracteriza-se como o 'alter' do direito oficial, mesmo que em conflito com este a partir das lutas das comunidades". LUDWIG, Celso Luiz. Para uma Filosofia Jurídica da Libertação: Paradigmas da Filosofia, Filosofia da Libertação e Direito Alternativo. Florianópolis: Conceito Editorial, 2006, p. 207. 
Há que se ressaltar, neste momento, que a total negação da legitimidade do poder punitivo, de acepção eminentemente abolicionista, constituiu-se também em um risco às garantias constitucionais que vieram a posteriori, pois, em sendo vanguarda, não apresentaram, de fato, respostas que fossem convincentes ao à época neófito ideal proposto, eis que baseadas em leis naturais despidas de mecanismos de contenção à intromissão punitiva privada, nem mesmo para evitar a preponderância da lei do mais forte (DOS SANTOS, 2006, p.5).

Assim, a marcha pela constitucionalização e prevalência dos Direitos Fundamentais foi enveredada para a seara da identificação de que os débeis, os mais fragilizados economicamente, as minorias sociais, em geral advindas de uma casta inferior, eram, de fato, os mais atingidos por aquele mecanismo repressivo estatal, e que, por esse motivo, era necessário o resgate de garantias formais e, sobretudo, materiais indelevelmente incrustadas na gênese daquele ressurgido Estado Democrático de Direito, necessárias para o seu (re) equilíbrio.

Consignou-se, portanto, nas cartas magnas posteriores (e em especial a brasileira), o seu resgate, como forma de se recuperarem os seus ideais fundantes ${ }^{10}$.

A essência da cultura da teoria do garantismo e do direito penal mínimo caía como luva ao ideal proposto, que passava então pelo controle social permeado por cercanias indicadas pela figura do cidadão comum, titular de direitos fundamentais e indissociáveis a sua pessoa, impossíveis, portanto, de serem aviltados.

Basta perceber, para tanto, a acolhida que se deu no pensamento brasileiro de vanguarda, os quais acolheram a matriz garantista para atuação no ambiente processual.

Desse modo, o discurso de um novo modelo de Direito Penal, balizado pelos novos ventos democráticos, passou a ser a "caixa de ressonância" da sociedade, redundando em seu expresso reconhecimento e relevância, através da promulgação da Carta Magna Brasileira em 1988.

Passou-se, assim, a justificar não só em razão do status quo político vigente naquele momento histórico, mas também pela validade dos princípios fundamentais inseridos no texto

${ }^{10}$ Do ensinamento clássico do Mestre Argentino, Eugenio Raul Zaffaroni: [...] Admitir este tipo de pacto fundador significava ao mesmo tempo reconhecer a validade de princípios, tais como os da culpabilidade, da humanidade da pena, da igualdade, da proporcionalidade e da ressocialização. E isto sem que se perdesse de vista o caráter preventivo norteador da intervenção penal estatal, isto é, sem que se pusessem de lado os princípios da fragmentariedade e da subsidiariedade da tutela penal”.(ZAFFARONI, 2006, p.7). 
daquela Lei Maior de que no Estado Democrático de Direito, a intervenção penal deveria ser (re) vista como devendo ser a mínima possível ${ }^{11}$.

Contudo, ainda que a atual Constituição tenha sido calcada por aspirações humanistas e liberais, o modelo garantidor e o princípio da intervenção penal mínima não foram inteiramente atendidos. Os avanços até então foram paulatinamente obliterados por nocivas interferências (ZAFFARONI, 2006, p.11) e franqueados progressivamente pela admissão de maliciosos mecanismos e tipos penais porosos, tais como "crime hediondo", tipos imprescritíveis, além da outorga - o tal "cheque em branco" - praticamente sem limites, de poderes ao legislador infraconstitucional para criminalizar condutas e cominar penas, advertido por Cirino dos Santos como uma espécie de apartheid legislativo velado ${ }^{12}$.

Com efeito, foi a partir dos anos 1990 que todo o aparato garantidor e interventor mínimo estatal passou a ser açodado por novos(?) paradigmas que passaram a valorizar sobremaneira a prevenção penal positiva, desvinculando a pena da função protetora de bens jurídicos (ZAFFARONI, 2006, p.8).

Passou-se, então, gradativamente, à obtenção de um "novo" justificante social: de que através da prevenção penal positiva e o uso simbólico do Direito Penal, se conseguiria a total obediência às normas penais.

O ocaso passou a tomar conta do direito penal e processual penal, protagonizado pelas arbitrárias inserções estatais advindas, ocasionando: a) o ocaso das garantias formais; b) o ocaso das garantias materiais; e c) o ocaso do princípio de utilidade da intervenção penal (ZAFFARONI, 2006, p.9).

${ }^{11}$ Qual seja: “... necessariamente mínima, expressando, apenas e exclusivamente, a ideia de proteção de bens jurídicos vitais para a livre e plena realização da personalidade de cada ser humano e para a organização, conservação e desenvolvimento da comunidade social em que ele está inserido. Os anos 80 renovaram a discussão - que, nas décadas anteriores, ficara num segundo plano - sobre o Direito Penal que, devendo ser mínimo e garantístico, teria por missão a defesa dos direitos humanos”. (ZAFFARONI, 2006, p.8).

${ }^{12}$ Isto é: [...] através das definições legais de crimes e de penas o legislador protege interesses e necessidades das classes e categorias sociais hegemônicas, incriminando condutas lesivas das relações de produção e de circulação da riqueza material, concentradas na área da criminalidade patrimonial comum, características das classes e categorias sociais subalternas, privadas de meios materiais de subsistência animal: os tipos legais de crimes fundados em bens jurídicos próprios das elites econômicas e políticas da formação social garantem os interesses e as condições necessárias à existência e reprodução dessas classes sociais. Nessa medida, a proteção penal seletiva de bens jurídicos das classes e grupos sociais hegemônicos pré-seleciona os sujeitos estigmatizáveis pela sanção penal, os indivíduos pertencentes às classes e grupos sociais subalternos, especialmente os contingentes marginalizados do mercado de trabalho e do consumo social, como sujeitos privados dos bens jurídicos econômicos e sociais protegidos na lei penal. SANTOS, Juarez Cirino dos. Direito Penal: parte geral. Rio de Janeiro: LumenJuris, 2006, p. 11. 
O princípio da legalidade, por exemplo, passou a ser alvo da prática de sua descontinuidade e inobservância, em evidente afronta e contraste com a Constituição da República.

As cláusulas vagas, gerais e permeáveis à prática casuística, produzidas pelo legislativo, foram direcionadas intencionalmente para o benefício das elites em detrimento das demais, sendo então vala comum de um instrumento mascarado em forma da garantia da defesa social.

A parcialidade do sistema penal, a criminalização do sujeito e a separação de classes ganham contornos reais de seu objetivo primordial, que é o desenvolvimento de uma estratégia de controle social, precária e injusta (DOS SANTOS, 2006, p. 16).

Assim é que, em virtude do próprio antagonismo formador das classes sociais, que fomenta a desigualdade na distribuição de renda, e o ínfimo desenvolvimento social e familiar, acabam por dividir entre proprietários do capital e possuidores da força de trabalho (DOS SANTOS, 2006, p. 6), reforçando ainda mais o seu tendencionismo ${ }^{13}$.

A defesa social é, sem dúvida, argumento substancial de alguns para o arrefecimento da pena, sem que se (re) discuta seu caráter utilitário e preventivo ${ }^{14}$.

O convencionalismo, segundo Ferrajoli, passa a ser, então, elemento verificador e classificador do que é e o de que pode ser punível ${ }^{15}$.

${ }^{13}[. .$.$] Seja como for, é no processo de criminalização que a posição social dos sujeitos criminalizáveis revela sua$ função determinante do resultado de condenação/absolvição criminal: a variável decisiva da criminalização secundária é a posição social do autor, integrada por indivíduos vulneráveis selecionados por estereótipos, preconceitos e outros mecanismos ideológicos dos agentes de controle social - e não pela gravidade do crime ou pela extensão social do dano. A criminalidade sistêmica econômica e financeira de autores pertencentes aos grupos sociais hegemônicos não produz consequências penais: não gera processos de criminalização, ou os processos de criminalização não geram consequências penais; ao contrário, a criminalidade individual violenta ou fraudulenta de autores dos segmentos sociais subalternos, especialmente dos marginalizados do mercado de trabalho, produz consequências penais: gera processos de criminalização, com consequências penais de rigor punitivo progressivo, na relação direta das variáveis de subocupação, desocupação e marginalização do mercado de trabalho. DOS SANTOS, 2006, p. 13.

${ }^{14}$ Então é dito: [...] Nestas condições, se o homem está fatalmente determinado a cometer crimes, a sociedade está igualmente determinada - através do Estado - a reagir em defesa de sua própria conservação, como qualquer outro organismo vivo, contra os ataques às suas condições normais de existência. A pena é, pois, um meio de defesa social. Contudo, na defesa da sociedade contra a criminalidade, a prevenção deve ocupar o lugar central, porque muito mais eficaz do que a repressão". ANDRADE, Vera Regina Pereira de. A ilusão de Segurança Jurídica: do controle da violência à violência do controle penal. 2. ed. Porto Alegre: Livraria do Advogado, 2003, p. 68.

${ }^{15}$ Uma vez que: [...] Este princípio exige duas condições: o caráter formal ou legal do critério de definição do desvio e o caráter empírico ou fático das hipóteses de desvio legalmente definidas. O desvio punível, segundo a primeira condição, não é o que, por características intrínsecas ou ontológicas, é reconhecido em cada ocasião como imoral, como naturalmente anormal, como socialmente lesivo ou coisa semelhante. É aquele formalmente indicado pela lei como pressuposto necessário para a aplicação de uma pena, segundo a clássica fórmula nullapoena et nullumcrimensine lege. Por outra parte, conforme a segunda condição, a definição legal do desvio deve ser produzida não com referência a figuras subjetivas de status ou de autor, mas somente a figuras empíricas e objetivas 
Desse modo, portanto, o modelo garantista se encaminha para a busca de alternativas concretas de combate a um ideal a ser superado, que é a submissão do juiz à lei, invariavelmente sustentada por elementos discriminatórios e arbitrários, que sustentam em seu bojo, conteúdos incertos, revestidos, em verdade, de instrumentos abusivos de negação de condutas perversamente ontológicas ${ }^{16}$.

Tal proposição passa, necessariamente, pelo total desapego do juiz a qualquer outro elemento senão a sua submissão à lei, como equivalência ao princípio da reserva legal, na medida em que não pode qualificar como delitos todos (ou somente) os fenômenos que considere imorais, ou, em todo caso, merecedores de sanção, mas apenas (e todos) os que, independentemente de sua valoração, venham formalmente designados pela lei como pressupostos de uma pena. A segunda condição comporta, além disso, o caráter absoluto da reserva da lei penal, em virtude da qual a submissão do juiz é somente à lei (FERRAJOLI, 2014, p. 39).

Há, portanto, indiscutivelmente, um marco teórico também neste momento. Ao invocar a reserva legal, rebatizada de "mera legalidade" direcionada aos juízes e a reserva absoluta de "estrita legalidade" ao legislador, o garantismo delineia um próximo passo racional formador do convencionalismo penal, que remete às únicas ações taxativamente indicadas pela lei, dela excluindo qualquer configuração ontológica ou, em todo caso, extralegal (FERRAJOLI, 2014, p. 39).

Sendo o modelo garantista um modelo coerente e racional em prol dos Direitos Fundamentais, balizado na concepção da intervenção estatal mínima, como forma de controle e limitação daquele poder artificial, tem-se, assim mesmo, preocupações relevantes quanto a hipóteses de ardis antigarantistas fundamentados justamente como já visto na chamada defesa social ou da prevenção especial (FERRAJOLI, 2014, p. 38); há, de fato, ausência de condicionantes limitadores.

de comportamento, segundo a outra máxima clássica: nullapoenasine crimine et sine culpa". ANDRADE, Vera Regina Pereira de. A ilusão de Segurança Jurídica: do controle da violência à violência do controle penal. 2 . ed. Porto Alegre: Livraria do Advogado, 2003. 2ed. p. 38.

${ }^{16}$ No qual define Luigi Ferrajoli: “[...] portanto, não admite normas que criam ou constituem ipso jure as situações de desvio sem nada prescrever, mas somente regras de comportamento que estabeleçam uma proibição, quer dizer, uma modalidade deôntica, cujo conteúdo não pode ser mais do que uma ação, e a respeito da qual seja aleticamente possível tanto a omissão quanto a comissão, uma exigível e a outra obtida sem coação, portanto, imputável à culpa ou responsabilidade de seu autor “. FERRAJOLI,2014, p. 39. 


\section{FLEXIBILIZANDO AS GARANTIAS NO PROCESSO PENAL: JUIZ NATURAL VERSUS O 'JUIZ DE ENCOMENDA'}

As garantias constitucionais, como se sabe, ocupam especial destaque dentro do Processo Penal. Ramo do Direito Público, é inegável que é dele a maior aproximação com o Texto Constitucional, vez que ao lidar com as liberdades, possui especial relevância no controle da arbitrariedade do jus puniendi estatal via controle social do Direito Penal, por exemplo.

O marco teórico construído por Ferrajoli estabelece que dentro da esfera do inegociável o princípio do juiz natural existe justamente para prevenir que a influência de outros poderes impeça a manutenção da imparcialidade do sujeito juiz e os espaços democráticos da persecução penal no exercício da jurisdição ${ }^{17}$.

$\mathrm{O}$ processo penal em sendo o modelo limite impede a existência de atos deconstrangimento refratários ao filtro constitucional de seus atos processuais. Dito de outra forma, a concepção democrática do sistema acusatório não permite sequer a possibilidade da incompreensão de que no jogo processual, os atos judiciais devam ser bem definidos e executados por seus atores processuais principais (defesa, acusação e julgador) - sem que cada um interfira na característica do outro -, não comportando qualquer possibilidade de que ainda exista o ranço do sistema inquisitório como sugerem alguns ou misto, outros.

Notável, destarte, que o princípio do juiz natural assegure, sobremaneira, a figura do julgador independente acima de qualquer tentativa de manipulação políticaou até midiática, consagrando, assim, o direito fundamental do acusado de '[...] saber, de antemão, qual o órgão e o juiz competente para o seu julgamento, quanto o de contar com mecanismos que assegurem a imparcialidade do julgador' (CASARA, 2017, p. 194).

Antítese do juiz constitucional é o 'juiz de encomenda', aquele que por razões politicas e econômicas - ambas muito próximas da cartilha neoliberal - define muito bem a quem será direcionado os atos judiciais da 'lei e a ordem': a camada da população incapaz de produzir ou consumir, ou os inimigos públicos daqueles que detêm o poder político ou econômico (CASARA, 2017, p. 199).

\footnotetext{
${ }^{17}$ Sobre a definição: “[...] O princípio do juiz natural é ao mesmo tempo uma garantia do indivíduo processado e da própria atividade jurusdicional. Essa garantia integra a 'Constituição processual criminal' (Canotilho e Moreira); ao acusado deve estar assegurada a certeza de que não será processado e julgado por pessoas que não integram os órgãos jurisdicionais definidos na Constituição da República ou que tenham interesse em sua punição". CASARA, Rubens. Juiz Natural à luz do Processo Penal do Espetáculo: os casos 'operação lava jato' e 'mensalão'. In MARTINS, Cristiano Zanin; MARTINS, Valeska Teiexeira Zanin; VALIM, Rafael. O caso Lula: a luta pela afirmação dos direitos fundamentais no Brasil. São Paulo: Contracorrente, 2017.
} 
Desta forma, é velado o desprezo neoliberal pelo direito, eis que aqueles que passaram a cultuar o mantra do mercado, passaram, também, a cultuar a eficiência econômica pregada e propagada sem qualquer cerimônia por Hayek e Friedman para dentro do Processo Penal, como se ele - O Direito - fosse produto, coisa e bem negociável de um Estado outrora social e de garantias - welfarestate -, para um Estado Mínimo ${ }^{18}$.

\section{QUE PROMOTOR É ESSE COM NOVOS PRINCÍPIOS PROCESSUAIS PENAIS?}

A letra de Eduardo Dusek apontava com acidez peculiar: "Que rei sou eu, se tenho generosidade?/Que rei sou eu, com fé e com honestidade?/Se desconheço autoridade sem vaidade, que rei sou eu? Eu só sou rei porque o rei de lá morreu? Eu só sou rei porque o rei de lá morreu/Que rei sou eu, se tenho tanta amizade?/Com a ferocidade da dignidade, que rei sou eu?". Não sem razão a letra da música cai como luva no atual panorama político brasileiro.

Vivemos, por certo, em tempos estranhos.

Não há nada comparado a representatividade coletiva que foi entregue ao Ministério Público, especialmente após a Constituição da República de 1988.

Não é ousado dizer que tudo, absolutamente tudo mudou a partir da aderência do Ministério Público ao novo texto constitucional.

Repetir a frase de Maquiavel "dê poder ao homem e descubra quem ele realmente é", não é, de certa forma, nenhum exagero.

É proposital.

\footnotetext{
${ }^{18}$ Neste sentido: “A sociedade, anota Miranda Coutinho, seguindo a indicação de Hayek e Friedman, procedeu a um câmbio epistemológico, abandonando a relação causa efeito para engolir a eficiência como parâmetro de atuação, exigida até o princípio constitucional (CF/88 art. 37, caput). Confundindo efetividade (fins) com eficiência (meios), grudando falsamente os significados como sinônimos, na ânsia de melhorar a realidade, muito autores jurídicos caem na armadilha do discurso neoliberal, ao preço da exclusão (sempre existem vítimas, ecoa Dussel) e da democracia, por se vilipendiar, necessariamente os 'direitos e garantias' constitucionais, rumo ao que se chama de 'mercado eficiente', com inexoráveis efeitos no modelo de aplicação do Direito, como defende ingênua e astutamente a escola da Análise Econômica do Direito". MORAIS DA ROSA, Alexandre. Direito de Família 'Total Flex'. ABREU, Pedro; OLIVEIRA, Pedro Miranda. Direito e Processo: estudos em homenagem ao Desembargador Norberto Ungaretti. Florianópolis: Conceito, 2007. p. 28.
} 
Necessário é resgatar aquilo que Rubens Casara (2016, p. 157 e ss.) contribuiu para desvelar o mito da imparcialidade do Ministério Públicoque permeia o imaginário do senso comum dos juristas e não juristas.

Casara, naquela obra, discorre que não se poderia esperar outra coisa senão a submissão do jurisdicionado por aquele que através do discurso, apresenta a verdade.

O plano da dogmática processual penal e sua visão cartesiana jamais se preocupou em explicá-los, pelo contrário, sempre legitimou o discurso de que aquele que nos representa está acima de qualquer suspeita - a chamada bondade dos bons por Werneck Vianna - e que aquele que vier a atacar o mito, pode significar a punição do transgressor ${ }^{19}$.

Dito de outra forma, não surpreende que a sociedade, esteja acostumada a apresentação de mitos que reforçam a opressão estatal através do direito penal enquanto fórmula de controle social - aqui já consignado -, o processo penal como seu mero instrumento, e a apresentação de atores jurídicos envolvidos (juiz, promotor, defensor, etc.), tudo, portanto, para conferir-lhe legitimidade e crença.

Todo o mito, no caso de que o Ministério Público é imparcial, é fundado na semiologia do discurso, vez que não se pode pensar na construção de um mito sem o uso da linguagem (CASARA, 2016, p. 157 e ss.).

A edificação desse mitoda imparcialidade do Ministério Público é mais do que evidenciada no cotidiano forense por aqueles que se veem como paladinos da justiça encastelados no gabinete da Promotoria da Moralidade Administrativa, por exemplo.

Mas o mito para ser real, precisa da crença, que é a consequência daquele que acredita naquilo que lhe foi imposto e o fundamenta vez que “... é dogmático, isto é, apresenta-se como

\footnotetext{
${ }^{19}$ Vale aqui citá-lo diretamente: "[...] a violação do mito, envolto em clima de temor, pode significar a punição do transgressor, a necessidade de rituais de purificação e, nos casos dos mitos jurídicos, a reforma ou anulação das decisões judiciais tomadas ao arrepio da mitologia que cerca (e existem várias 'cercas jurídicas') o tema decidido (assim, por exemplo, afastar-se o mito da verdade real no processo penal pode ser punido pelo censor-tribunal com a realização de nova - e desnecessária - instrução criminal ao arrepio da opção constitucional pelo sistema acusatório). Por outro lado, a superação de determinados mitos pode significar a ruptura com uma tradição autoritária e o início de uma nova prática judicial comprometida com a concretização do Estado Democrático de Direito". CASARA, 2016, p. 158.
} 
uma verdade que não precisa ser provada e nem admite contestação; a aceitação do mito é, portanto, acrítica; o mito é inatingível pela razão" (CASARA, 2016, p. 157 e ss.).

De outra forma o que se quer dizer é que criou-se o mito de que o Ministério Público seria imparcial, e que, portanto, teria ele o domínio sobre a verdade sobre todos os demais, o que fundamentou a crença de todos nós.

Fomos, então cooptados pelo discurso mítico que foi legitimado (crença) pelo processo penal afim de dar-lhe o ar de racionalidade.

A ideia da imparcialidade, desse modo, choca diretamente com a concepção democrática do processo penal, haja vista que é um processo delineado e formado por partes, logo não há como conceber um sujeito (Promotor) ser uma "parte imparcial” (CASARA, 2016, p. 169 e ss.).

Não se pode dar o que não se tem, logo, em sendo uma parte, o Ministério Público é parcial na verdadeira acepção da palavra, isto é, é apenas uma parte de um todo.

Ainda assim, não se quer deixar de reconhecer o papel importante do Ministério Público, seu lugar é de instituição essencial à função jurisdicional do Estado, defendendo, sem exageros, a ordem pública, a democracia e os interesses sociais e indisponíveis previstos no texto da Constituição da República (arts. 127 a 130).

Por esta razão, o presente texto defende que há uma mistura de características atuais do Ministério Público no Brasil: se por um lado existem elementos do 'prosecutor' eleito pelo povo tal qual é aplicado no modelo estadunidense, com poderes de negociação, barganha e proposição de acordos - atualmente através da chamada colaboração premiada na Lei 12.850/2013 - de outro existem características que resistem ainda pelo tempo, tal qual o modelo francês, baseado, assim, na acusação formal dirigida ao réu e a sua sustentação em juízo(CASARA, 2016, p. 164).

Aqui, então, reside na ideia de discutir até que ponto, teria ou não a legitimidade o Promotor em negociar no Processo Penal - a delação premiada -, sem que se esqueça de que há limites democráticos para preservar o que é regra e o que é exceção. Dito de outra forma, até que ponto teria a legitimidade para barganhar sem que houvesse algum tipo de choque entre os conjuntos de regras e princípios. 
O resgate da Ordem Democrática com o advento da Constituição da República em 1988 consagrou, em definitivo a concepção de norma regra e norma princípio.

Assim, ainda que o presente texto não tenha a pretensão de discutir norma e princípio, é certo que enquanto a primeira descreve a conduta e seu critério deontológico, a segunda tem o caráter descritivo do seu objetivo e da finalidade.

Daí que, prima facie, o princípio, ab ovo, se sobrepõe a norma, vez que ela deve estar sempre fundamentada no princípio. Havendo conflito entre eles, deverá ser analisado com base na ponderação dos interesses, em outras palavras, os princípios na hipótese jamais se anularão, mas, no caso em concreto, deverão prevalecer um sobre o outro.

Os princípios da obrigatoriedade e da indisponibilidade, por suas especiais características, demonstram o exato perfil do Processo Penal como ramo essencial do Direito Público, dada as suas particularidades que lhe concebem a inflexibilidade ${ }^{20}$ de seu perfil, como elemento indissociável do garantismo penal.

A pretensão punitiva do Estado (jus puniendi) se notabilizou pelo uso racional da figura do processocomo procedimentoem contraditório com a primazia das garantias. A ação penal em regra é pública na exata dicção legal do art. 129, inciso I da Constituição da República.

Sem embargo de outras considerações, é o Ministério Público o dominis litis da ação penal e de que os crimesprocessados e julgados sob essa condição estão submetidos na sua integralidade ao princípio da obrigatoriedade na medida em que estará aquele sujeito processual - o Promotor de Justiça - obrigado a oferecer a denúncia quando verificado for que a conduta noticiada através do indício, se ajusta a figura típica e antijurídica da Lei Penal.

\footnotetext{
${ }^{20}$ Ponto central a questão da obrigatoriedade, são elucidativas as seguintes considerações: "Portanto, conforme a posição majoritária, o princípio da legalidade no processo penal corresponde à obrigatoriedade da persecução punitiva ou, nas palavras de Jacinto Coutinho, "é praxe ser tratado (o princípio da obrigatoriedade) por princípio da legalidade, em face de fundar um dever do órgão oficial de acusação". Ele caracteriza, assim, "a ideia de que o MP está obrigado a proceder e dar acusação por todas as infrações de cujos pressupostos - factuais e jurídicos, substantivos e processuais- tenha tido conhecimento e tenha logrado recolher, na instituição, indícios suficientes". Logo, há um dever de acusação decorrente da lei que se impõe quando houver indícios de materialidade e autoria suficientes da ocorrência de uma infração penal, o que não pode ser influenciado ou renunciado por razões discricionárias ou por motivos alheios à simples averiguação da existência ou não do crime a partir das provas obtidas". VASCONCELOS, Vinícius Gomes de. Barganha e Justiça Criminal Negocial. São Paulo: IBCCRIM, p. 36.
} 
É por isso que a máxima necdelictamaneantimpunita condiciona que ao não permitir que nenhum delito permanecerá impune obriga o Parquet a não ter escolha por não denunciar, a rigor.

Na mesma toada não é dada a disponibilidade da ação penal àquele que a representa, após a sua propositura, em consonância ao que dispõe o art. 42 do Código de Processo Penal.

Não é demais reforçar que tal sistematização retratada pelo Código de Processo Penal, versa acerca da ação penal pública incondicionada, mas não na ação penal pública condicionada ou na ação penal privada cuja iniciativa é exclusiva da vítima.

Como se sabe, ainda que os mesmos princípios aplicáveis à ação penal pública incondicionada são automaticamente dirigidos também para a ação penal pública condicionada, a análise encontra restrições, vez que, sem embargo de outras questões, a representação é mera condição de procedência da ação penal, sem o que o Ministério Público no exercício de sua titularidade dependerá da autorização expressa da vítima.

Com o advento da Lei 12.850/2013, houve um câmbio dessa espécie de discricionariedade atribuída ao Ministério Público, haja vista que claramente criou mecanismos e procedimentos contrários ao dever de acusar. O Ministério Público pode antes mesmo da existência do processo penal requerer não só a diminuição de pena como também o seu próprio perdão, sendo capaz de desconstruir todo o arcabouço de paradigmas atribuídos até então àquele titular da ação penal.

\section{A COLABORAÇÃO PREMIADA COMO ESPÉCIE DE BLITZKRIEG NO PROCESSO PENAL.}

O Império Nazista criou uma formidável estratégia militar vencedora de guerras que combinava velocidade, surpresa e medo, a Blitzkrieg (literalmente "guerra-relâmpago"). Referida tática envolvia unidades de tanques leves, apoiadas por aeronaves e infantaria, abrindo caminho através das linhas inimigas e rumando rapidamente para capturar objetivos antes que o inimigo tivesse tempo de reagrupar-se. O sucesso nos primeiro anos da guerra foi imediato (CAWTHORNE, 2015, p. 6). 
Os três pilares da técnica concebida por Hitler - velocidade, surpresa e medo - pode ser perfeitamente associada ao presente texto se analisarmos a forma, justificativa e o resultado do instituto da delação premiada/colaboração premiada recentemente aplicada para casos ligados ao combate à corrupção no Brasil.

Há algumas obras de relevo sobre delação premiada que apontam para ações que são chocantes por seu viés autoritário e maniqueísta ${ }^{21}$, e segundo esses doutrinadores demonstrammediante reflexões de viés constitucional o modelo extremamente controvertido quando analisado pelo horizonte do processo segundo a teoria dos jogos (dilema do prisioneiro $)^{22}$, proposto na obra de Alexandre Morais da Rosa (2013).

Os espaços democráticos no Processo Penal Brasileiro construídos desde 1988, portanto, encontram-se em risco em decorrência da desconsideração de sua própria função aqui debatida para a eficiência da proposta baseada sempre em técnicas de intimidação e pressão generalizada para a aceitação do acordo.

A redução dos limites racionais e democráticos regrados pelo processo penal em razão do interesse pela punição coloca um dilema ao acusado: aguardar passivamente por todo o processo a confirmação de sua presunção - o tempo e a morosidade do judiciário colaboram para corroê-lo psicologicamente - ou, então, não arriscar e optar pela solução mais rápida que é colaborar.

Nada disso é novo, de uma forma ou de outra no próprio procedimento sumaríssimo é encontrado situações dessa natureza, seja na transação penal que é proposta e se negada for, pode muitas vezes redundar em um pedido de arquivamento do termo circunstanciado, sempre é alvo de críticas.

Nos Estados Unidos da América do Norte são várias as atrocidades cometidas durante fases preliminares ao processo ou após a sua instalação, quando promotores de justiça legalmente se utilizam da barganha claramente como um "vale tudo", verdadeira modalidade contemporânea da tortura medieval ${ }^{23}$.

\footnotetext{
${ }^{21}$ Veja-se: VALLE, Juliano Keller do. Crítica a Delação Premiada: uma análise através da Teoria do Garantismo Penal. São Paulo: Conceito Editorial, 2012.

22Veja-se: MORAIS DA ROSA, Alexandre. Guia Compacto do Processo Penal conforme a Teoria dos Jogos. Rio de Janeiro: Lumen Juris, 2013.

23“[...] inúmeros são os exemplos de evidentes pressões e intimidações direcionadas aos acusados na justiça criminal estadunidense, de modo que dois casos são rotineiramente citados por sua arbitrariedade. Em Bordenkircher v. Hayes (julgado em 1978), a Suprema Corte confirmou a admissibilidade de uma barganha realizada nas seguintes condições: o réu era acusado de emitir um cheque falsificado, mas por ser reincidente estava sendo processado com base em lei que autorizava o aprisionamento perpétuo para tais situações (situação frisada coativamente pelo acusador no momento da negociação); assim, o promotor ofereceu proposta acordo com a sanção penal de cinco
} 
A comparação do uso das prisões temporária e preventiva (velocidade e surpresa) como táticas de aniquilamentoe seus mecanismos de pressão cooperativa (medo) no campo das delações brasileiras com a Blitzkrieg é inevitável.

Entendo modestamente que a forma (contrária ao processo penal democrático pós 1988), a justificativa (política e midiática) e o resultado (prisões cautelares conjugada com um suposto apoio popular) de inúmeras delações apresentadas por indiciados/acusados sem o devido filtro das garantias podem contaminar de forma irreversível não só o sistema acusatório que ainda não alcançamos na totalidade, mas desviar o eixo democrático que ainda vivemos.

Se a reprodução dos fatos no processo na forma tradicional como conhecemos já é problemática, o que diremos da 'verdade' apontada por aquele que é pressionado a delatar?

É bom lembrar que (ainda) existe revisão criminal.

Aprendemos na universidade que juiz não é parte e que a prova produzida de ofício o faz muito mais próximo do inquisidor - de triste memória -, do que do juiz garante, assim comoqualquer quebra as regras do jogo processual, o torna nulo.

Biltzkrieg, Delação Premiada e Juiz 'Batman' de um lado e eu(réu) do outro. Afinal, quem 'me salva da bondade dos bons'?

\section{CONSIDERAÇÕES FINAIS}

Inegavelmente a chamada 'justiça negociada' não se trata de assunto novo na doutrina criminal e processual brasileira, já que desde o ano de 1995, a implantação dos Juizados Especiais Criminais com o advento da Lei 9.099/95, estabeleceu um revolução não só na prestação jurisdicional, mas na atuação do Ministério Público através da transação penal e da suspensão condicional do processo.

anos em uma previsão legal de mínimo dois e máximo dez anos; diante disso, o acusado rejeitou a barganha, exercendo seu direito a julgamento, em que, ao final, foi condenado à prisão perpétua; interposto o recurso, a punição atribuída em razão da não realização do acordo foi declarada constitucional. Ou seja, 'a Suprema Corte fomentou um sistema judicial bizarro, em que o crime de emitir um cheque falso no valor de U\$\$ 88 representa uma sanção penal de cinco anos enquanto o 'crime' de exercer o direito ao julgamento é punido com prisão perpétua, descrição que inquestionavelmente caracteriza um 'pesadelo para um visão continental de justiça' ". VASCONCELLOS, Vinícius Gomes de. Barganha e Justiça Criminal Negocial: análise das tendências de expansão dos espaços de consenso no processo penal brasileiro. IBCCRIM, São Paulo, p. 164.

Rev. de Direito Penal, Processo Penal e Constituição | e-ISSN: 2526-0200| Maranhão | v. 3 | n. 2 | p. 181 - 197 | Jul/Dez. 2017 
Igualmente, no Brasil, de forma fragmentada seja no Código Penal ou em legislações esparsas, aqui e acolá, a delação premiada ou instrumentos de incentivos a colaboração premiada existiam há anos, ainda que de forma incipiente.

A promulgação da Lei 12.850/2013 trouxe problemas de ordem constitucional e processual penal que de forma açodada mitigou os princípios que davam garantia ao acusado, o julgamento mediante regras minimamente aceitáveis através do jogo processual até então vigente.

A questão para os próximos anos será a de que será necessário estabelecer regras ainda mais claras de como será ou não validada a colaboração premiada - seja na fase do inquérito ou na fase judicial - com o objetivo de se evitar juízos de condenações ou de absolvições - por que não? - baseadas em um meio de prova eticamente discutível e destituído de uma tradição jurídica no Brasil.

\section{REFERÊNCIAS}

ANDRADE, Lédio Rosa de. O que é Direito Alternativo? <Disponível em http://www.amc.org.br. Acesso em 20 de jun. de 2007.

ANDRADE, Vera Regina Pereira de. A ilusão de Segurança Jurídica: do controle da violência à violência do controle penal. 2. ed. Porto Alegre: Livraria do Advogado, 2003.

CASARA, Rubens R. R. Processo Penal do Espetáculo: ensaios sobre o poder penal, a dogmática e o autoritarismo na sociedade brasileira. Florianópolis: Empório do Direito, 2016.

CASARA, Rubens R. R. Juiz Natural à luz do Processo Penal do Espetáculo: os casos 'operação lava jato' e 'mensalão'. In MARTINS, Cristiano Zanin; MARTINS, Valeska Teiexeira Zanin; VALIM, Rafael. O caso Lula: a luta pela afirmação dos direitos fundamentais no Brasil. São Paulo: Contracorrente, 2017.

CAWTHORNE, Nigel. Blitzkrieg: oplano estratégico de Hitler para conquistar a Europa. São Paulo: M. Books, 2015.

FERRAJOLI, Luigi. Direito e Razão: Teoria do Garantismo Penal. 2.ed. São Paulo:Revista dos Tribunais, 2014.

LUDWIG, Celso Luiz. Para uma Filosofia Jurídica da Libertação: Paradigmas da Filosofia, Filosofia da Libertação e Direito Alternativo. Florianópolis: Conceito Editorial, 2006.

MORAIS DA ROSA, Alexandre. Guia Compacto do Processo Penal conforme a Teoria dos Jogos. Rio de Janeiro: Lumen Juris, 2013. 
MORAIS DA ROSA. Direito de Família 'Total Flex'. ABREU, Pedro; OLIVEIRA, Pedro Miranda. Direito e Processo: estudos em homenagem ao Desembargador Norberto Ungaretti. Florianópolis: Conceito, 2007.

PASOLD, Cesar Luiz. Metodologia da pesquisa jurídica: teoria e prática. 13. ed. Florianópolis: Conceito Editorial, 2015.

SANTOS, Juarez Cirino dos Santos. Direito Penal: Parte Geral. 21.ed. Rio de Janeiro: LumenJuris, 2006.

VALlE, Juliano Keller do. Crítica a Delação Premiada: uma análise através da Teoria do Garantismo Penal. São Paulo: Conceito Editorial, 2012.

VASCONCELOS, Vinícius Gomes de. Barganha e Justiça Criminal Negocial. São Paulo: IBCCRIM, 2016.

ZAFFARONI, Eugênio Raul. Direito Penal Brasileiro Volume I - Parte Geral. 5. ed. São Paulo: Revista dos Tribunais, 2006. 